\title{
Studies on the Relationship Between Coronaviruses from the Intestinal and Respiratory Tracts of Calves
}

\author{
By \\ D. J. Reynolds, T. G. Debney, G. A. Hall, L. H. Thomas, \\ and K. R. Parsons \\ A.F.R.C. Institute for Research on Animal Diseases, Compton, Newbury, \\ Berkshire, United Kingdom \\ With 3 Figures \\ Accepted November 1, 1984
}

\section{Summary}

An immunofluorescence test on smears of nasal epithelial cells was used to detect coronavirus infection in the respiratory tract of calves. Thirteen gnotobiotic calves were infected with coronavirus isolates derived from faeces or respiratory material: virus was detected in faeces and nasal swabs from all animals. In 115 calves from a field survey, there was a significant association between coronavirus excretion from both respiratory and enteric routes in calves with diarrhoea. In a further 12 calves, at necropsy, the predilection sites for coronavirus growth were the distal small intestine, large intestine and the epithelia of the nasal eavity and trachea. Antigen was not found in lung tissue by immunofluorescence or immunoperoxidase staining.

Infection with enteric coronavirus induced immunity to reinfection and to heterologous challenge with two coronavirus isolates derived from the respiratory tract. Nine coronaviruses were cultivated, cloned and antisera to three were prepared in pigs. There was complete virus neutralisation in tests with homologous sera and significant cross reactions with the eight other isolates which were of intestinal and respiratory origin. Thus, these bovine coronavirus isolates belonged to the same serotype despite the source of virus.

\section{Introdnetion}

Coronavirus are important causes of upper respiratory tract illness, encephalitis, hepatitis and enteric disease in humans or animals (27). The 
intestine is the primary site for replication of transmissible gastroenteritis virus (TGEV) of pigs, canine and bovine coronavirus (BCV). Virus replication causes pathological changes in the intestinal villi and diarrhoea can result (10). Three coronaviruses are considered to be respiratory pathogens (14, $21)$; they are avian infectious bronchitis virus (AIBV), rat corona virus (RCV) and human coronavirus (HCV).

Culture adapted (20) and field strains (1) of BCV grew well in organ cultures derived from foetal bovine trachea, nasal mucosa (5) and bovine embryonic lung cell cultures (25), suggesting that although BCV is an enteropathogen, it might also infect the respiratory tract. Coronavirus infection of the respiratory tract was first demonstrated in gnotobiotic calves (24) by electron microscopy, organ culture cultivation and enzymelinked immunosorbent assay (ELISA). Immune electron microseopy and ELISA showed an antigenic relationship between the respiratory isolate and bovine enteric coronavirus, which was later confirmed (15). Subsequently rising antibody titres were found during $4 / 8$ outbreaks of ealf pneumonia and also in $7 / 18$ gnotobiotic calves which were inoculated with respiratory material (16).

This paper reports an investigation of the extent of infections and relationship between coronavirus found in the intestinal and respiratory tracts of calves. A search for virus antigen was undertaken in tissues and excretions from experimentally and naturally infected calves, followed by a study of reciprocal cross-protection in calves and neutralising ability on some of the isolates obtained.

\section{Materials and Methods}

\section{Field Outbreak Material}

Samples of faeces and nasopharyngeal swabs were taken from 115 farm ealves. These were collected during a survey of the micro-organisms present in outbreaks of calf diarrhoea; 69 calves had diarrhoea and the remaining 46 were clinically normal. A further 12 calves, identified during the survey as suffering from severe diarrhoea, were purchased and submitted for necropsy.

\section{Experimental Animals}

Nine gnotobiotic calves (2), aged $1-24$ days (Table 3, calves $1,2,3,6$ and 7 plus four others) were inoculated orally with coronavirus (strain E) derived from faeces (1). The inoculum was approximately $1 \mathrm{~g}$ of faeces from an infected gnotobiotic calf. Two of the calves (Table 3 , calves 2 and 3 ) were rechallenged with the same inoculum 14 or 21 days later. A third (Table 3 , calf 6 ) was challenged with strain $R 1$ and a fourth (Table 3, calf 7) with strain $\mathrm{R} 2$ by intranasal and intratracheal inoculation. $\mathrm{R} 1$ and $\mathrm{R} 2$ were respiratory strains of coronavirus derived from an outbreak of pneumonia in calves (24) or from a farm calf (Table 2, calf 11 ).

In addition, four gnotobiotic calves, aged 2-151 days (Table 3, calves 4 and 5 plus two others) were inoculated by the intranasal and intratracheal routes with coronavirus $R 1, R 2$ or $R 3$ derived from the respiratory tract (the latter from calf 1 , 
Table 2). Up to $30 \mathrm{ml}$ of infeeted lung washings or nasopharyngeal secretions, suspended in PBS, were inoculated.

Nasopharyngeal swabs (22) and faeces were taken on the day of inoculation and daily thereafter for up to 21 days. Two calves, inoculated with respiratory material, were killed and their tissues examined for distribution of coronavirus antigen.

\section{Necropsy Procedures}

Intestinal tissues were located and removed under deep anaesthesia prior to euthanasia (4). Respiratory tract tissues were removed after death. Sections (10 $\mu \mathrm{m}$ thick) were cut from frozen segments of tissue at 14 intestinal and 9 respiratory tract sites, fixed in acetone and stained by immunofluorescence. Tissues fixed in mercurie formol were dehydrated, embedded in paraffin wax, sections cut and stained by immunoperoxidase (11). The same antiserum was used in both staining methods.

\section{Detection of Coronavirus}

Suspensions of calf faeces ( 10 per cent $w / v$ ) were made in PBS and tested by ELISA for coronavirus (17). Epithelial cells from the nasopharyngeal swabs were prepared and examined by direct immunofluorescence using the method and controls described for respiratory syncytial virus (23). Coronavirus antibody for staining was raised in a gnotobiotic calf (17), conjugated with fluorescein isothiocyanate and used at a dilution of $1 / 160$. Similarly, sections of frozen or fixed intestinal and respiratory tissue were stained for coronavirus antigen by direct immunofluorescence or by an jndirect immunoperoxidase method (11), respectively.

\section{Oultivation of Coronavirus and Neutralisation Tests}

Nine coronaviruses isolated from the intestinal (5/9) or respiratory (4/9) tract were cultivated for three passages in human rectal tumour (HRT 18) cells (7) in the presence of trypsin $(10 \mu \mathrm{g} / \mathrm{ml}$ Sigma Type III) (19). After the third pass, virus was sonicated, passaged through a $0.22 \mu \mathrm{m}$ membrane filter and cloned in HRT cells by three serial passages at the terminal dilution for virus infectivity. A stock of each cloned strain was grown and stored in aliquots at $-70^{\circ} \mathrm{C}$.

Three of the eloned strains were used to prepare hyperimmune sera in gnotobiotic piglets aged one month. Purified virus (13) was emulsified with Freund's incomplete adjuvant and inoculated intramuscularly on two occasions, three weeks apart. Three weeks after the second injection the piglets were killed and bled for serum.

A neutralisation test was used to sereen the three antisera for activity against the nine coronavirus isolates. All sera were incubated at $56^{\circ} \mathrm{C}$ for 30 minutes to inactivate complement and then diluted 1 in 10 or 1 in 100 in HRT 18 maintenance medium (RPMI 1640). An equal volume of coronavirus was added, ineubated at $37^{\circ} \mathrm{C}$ for 1 hour and the infectivity of residual virus was assayed in HRT 18 cells. In every assay a negative control pig serum (immune to rotavirus) was tested in parallel with the immune serum.

\section{Results}

\section{Routes of Coronavirus Excretion and Clinical Findings}

The presence of coronavirus in samples of faeces and nasal swabs taken from farm calves is recorded in Table 1 . Coronavirus was detected in faeces and nasal swabs of 23 and 20 per cent of calves with diarrhoea and 0 and 4 per cent of normal calves. There was also a significant association $(p<.001)$ between the simultaneous detection of coronavirus in faeces and 
Table 1. Coronavirus excretion in paired faeces and nasal swabs from 115 calves during a field survey of enteritis outbreaks

\begin{tabular}{|c|c|c|c|c|}
\hline \multirow[b]{3}{*}{ Calf health } & \multicolumn{4}{|c|}{ Coronavirus detection in } \\
\hline & \multicolumn{2}{|c|}{ Faeces } & \multicolumn{2}{|c|}{ Nasal swabs } \\
\hline & + & - & + & - \\
\hline Normal $(n=46)$ & 0 & 46 & 2 & 44 \\
\hline Diarrhoeic $(n=69)$ & 16 & 53 & 14 & 55 \\
\hline
\end{tabular}

$+=$ coronavirus detected $;-=$ coronavirus not detected

nasal swabs in calves with diarrhoea, but there was no difference in detection of coronavirus in respiratory material from normal calves and those with diarrhoea, in the absence of excretion in faeces.

Inoculation of 13 gnotobiotic calves with coronavirus isolated from either the intestinal or respiratory tract resulted in infection of alimentary and respiratory tissues of all calves. They developed abnormal faeces, the severity varied from a transient change of colour to frank diarrhoea. No signs of respiratory disease were recorded. In 9 calves inoculated with coronavirus strain $\mathrm{E}$ shedding began in faeces after a mean prepatent period of 1.9 days (range $1-3$ days) and lasted 3.4 days (range $2-5$ days), nasal swabs were positive after a prepatent period of 2.1 days (range 1 4 days) for 3.9 days (range $1-7$ days). Coronaviruses $R 1,2$ or 3 were shed. in the faeces of the four calves after a mean prepatent period of 1.5 days (range $1-2$ days) for 4.0 days (range $3-5$ days). Nasal swabs were positive on the first day after inoculation for a mean period of 5.3 days (range $5-6$ days).

\section{Location of Coronavirus Antigen in Tissues}

Coronavirus antigen was detected in at least one tissue taken from 12 calves at necropsy (Table 2). All the calves came from field outbreaks of disease and had diarrhoea, but this was not necessarily the result of coronavirus infection as other enteropathogens were detected.

Coronavirus was found by immunofluorescence in intestinal and respiratory tissue in calves $1-8$, colon was the only site infected in calf 9 and respiratory infection alone was found in calves 10-12. Immunoperoxidase and immunofluorescence staining were used in parallel to detect coronavirus antigen in $190 / 202$ sections from 8/12 calves. The results agreed in 172/190 (90.5 per cent) and disagreed in $18 / 190$ (9.5 per cent) of cases. In the latter category, 14 of the sections were scored positive for coronavirus by immunoperoxidase and negative by immunofluorescence. Frequently, only small numbers of infected cells were located and these did not substantially alter the overall pattern of distribution of antigen found by immunofluorescence, no antigen was found in lung tissue stained by immunoperoxidase. 
Calf Coronaviruses

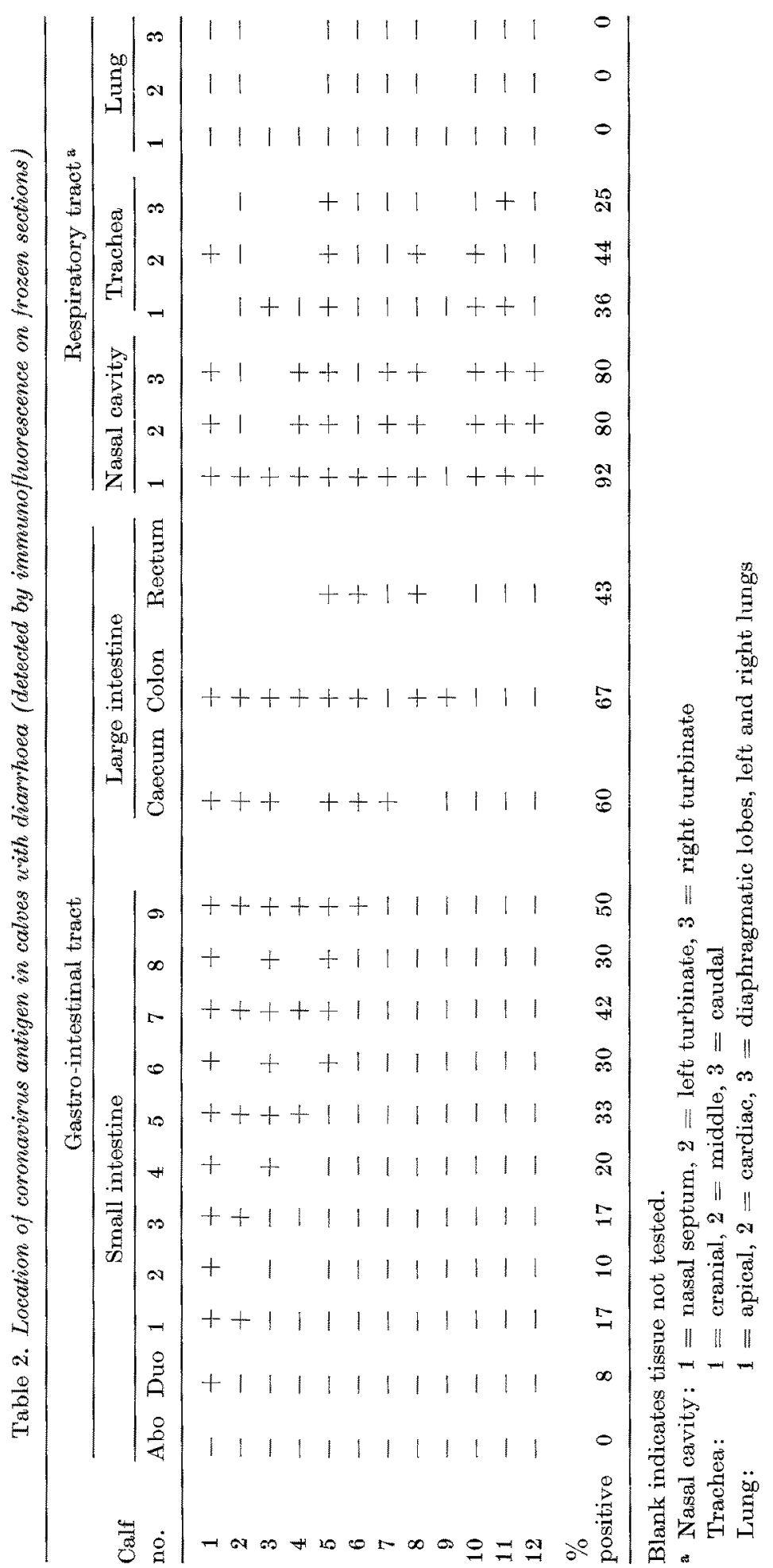


Coronavirus replication was widely distributed in calf 1 . Scattered enterocytes showed brilliant, cytoplasmic immunofluorescence in the duodenum, particularly over the tips of villi, which also stained by immunoperoxidase (Fig. 1). All 9 sites examined from the small intestine showed numerous infected enterocytes which covered most of the villi. Many cells, sloughed into the intestinal lumen, were infected. Occasionally enterocytes in the crypts contained coronavirus antigen, but no positive cells could be

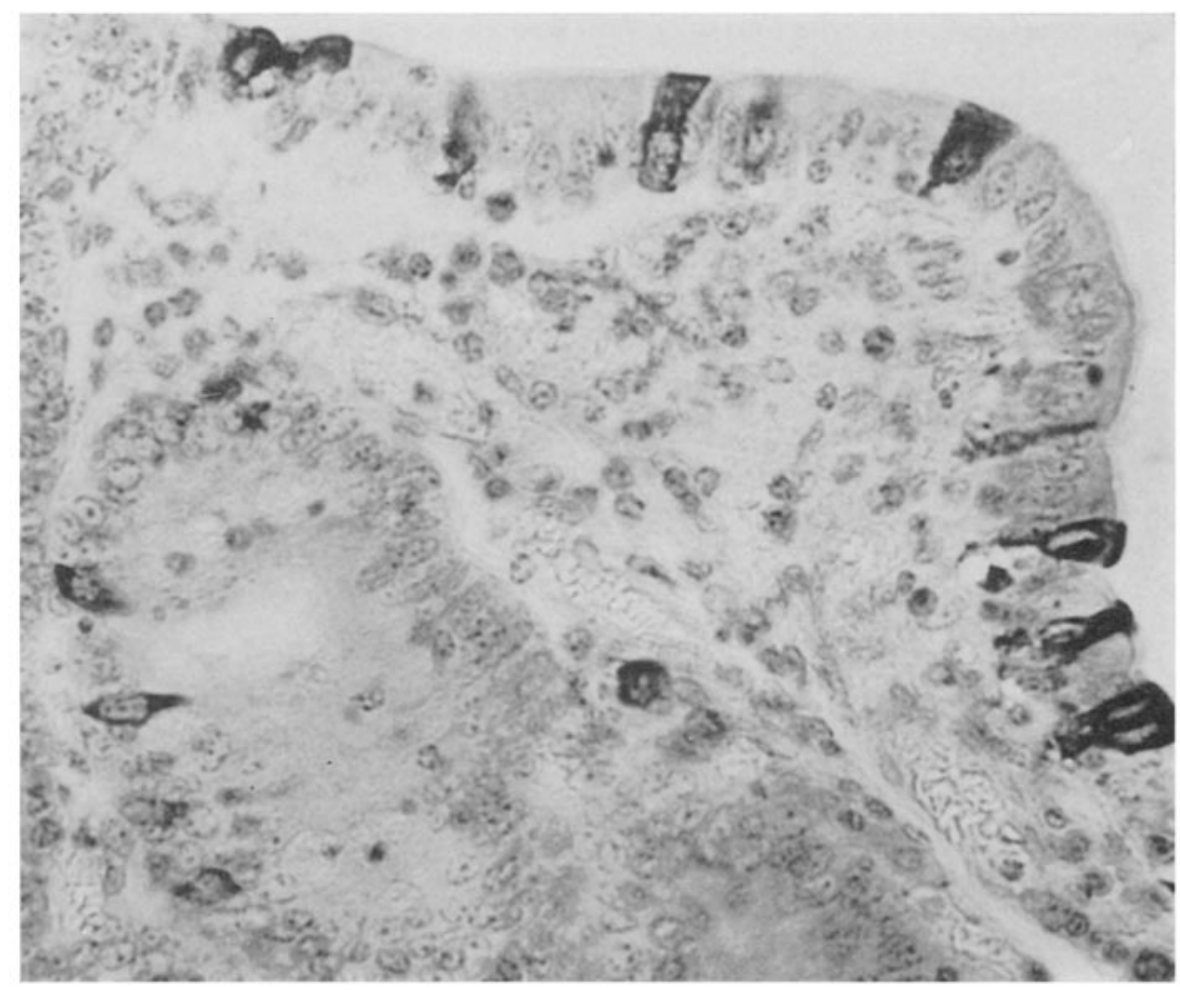

Fig. 1. Coronavirus-infected cells on the surface of a villus and in a crypt of the duodenum of calf 1 . Indirect Immunoperoxidase stain. $\times 525$

clearly identified in the lamina propria. In the caecum and colon most surface columnar epithelial cells and the majority of crypt enterocytes were affected. Caecum and colon were the only tissues infected in the intestines of calves 7 and 9 respectively. In both cases very small numbers of infected crypt cells were seen, however coronavirus was cultivated and cloned in HRT 18 cells from the colon contents of calf 9 . Infected cells in the rectum were found in three calves; they were surface columnar epithelial cells which were widely distributed in small numbers.

Pseudostratified, columnar, ciliated epithelial cells of the nasal cavity were infected by coronavirus in 11/12 calves. Some sections contained only 
a few, columnar cells within the epithelium. In other sections a large proportion of the columnar, ciliated epithelial cells were stained (Fig. 2). The distribution of intranasal infection appeared to be patchy. Connective, glandular and vascular tissues, underlying the epithelium were not affected. Columnar, ciliated cells were infected in the cranial trachea and cuboidal epithelial cells at the middle and caudal sites (Fig. 3). Affected cells were

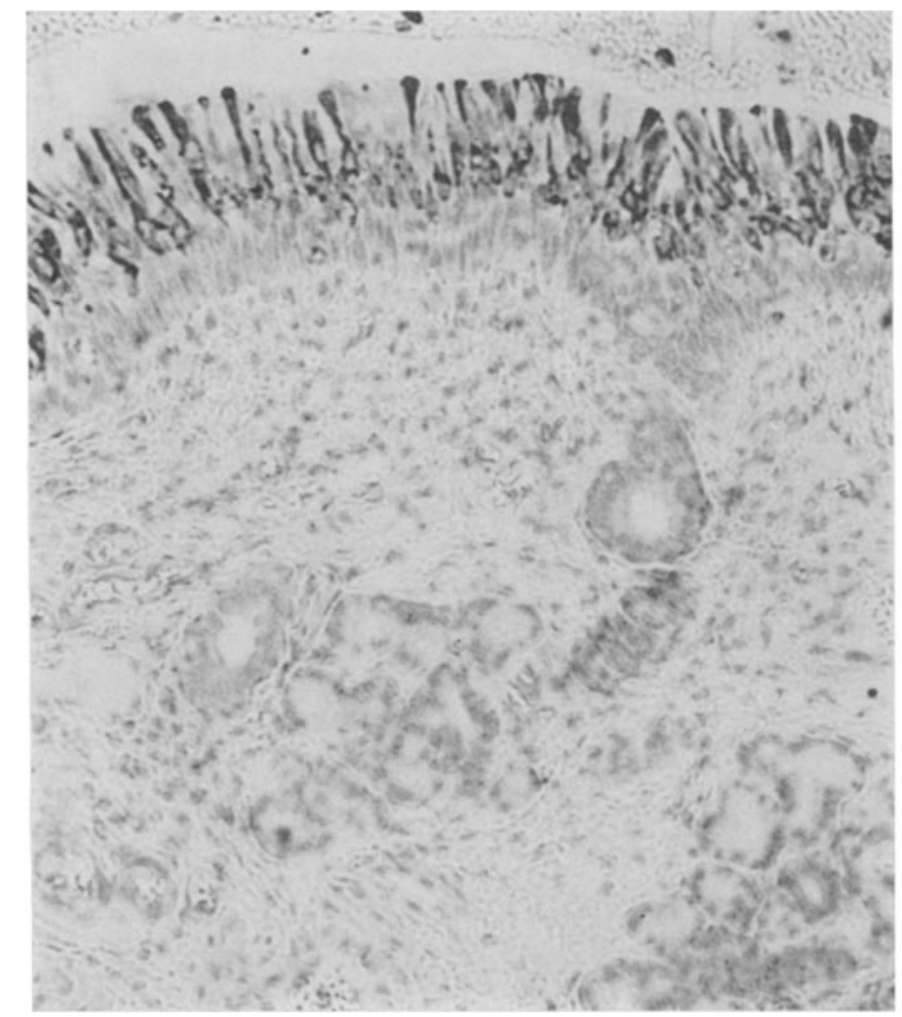

Fig. 2. Coronavirus-infeeted cells in the epithelium of the nasal septum of calf 1 . Glandular epithelial cells are not infected. Indirect Inamunoperoxidase stain. $\times 200$

evenly distributed throughout the lining epithelium of sections of trachea and the number of infected cells per section was always smaller in the middle and caudal sites than the cranial trachea.

An extensive search of two lung sections at three sites (Table 2) was made and no immunofluorescence was seen. The low level of background staining helped to ensure that no infected cells were overlooked.

The location of infected cells within affected respiratory tract tissues of calves 10,11 and 12 was similar to that in calves $1-9$, which also had intestinal infections. Table 2 indicates the predilection sites for coronavirus replication in 12 infected calves: they were distal sites in the small intestine, 
caecum, colon and upper respiratory tract tissues. Coronaviruses ( $\mathrm{R} 2$ or $\mathrm{R} 3$ ) derived from the respiratory tracts of calves 1 or 11 (Table 2) were used to inoculate two gnotobiotic calves, which were killed for necropsy five days later. Antigen was located by immunofluorescence, at small intestine sites $5-9$, caecum, colon and rectum. The three sites in the nasal cavity and levels 1 and 2 of trachea were infected but no antigen was found in the lung.

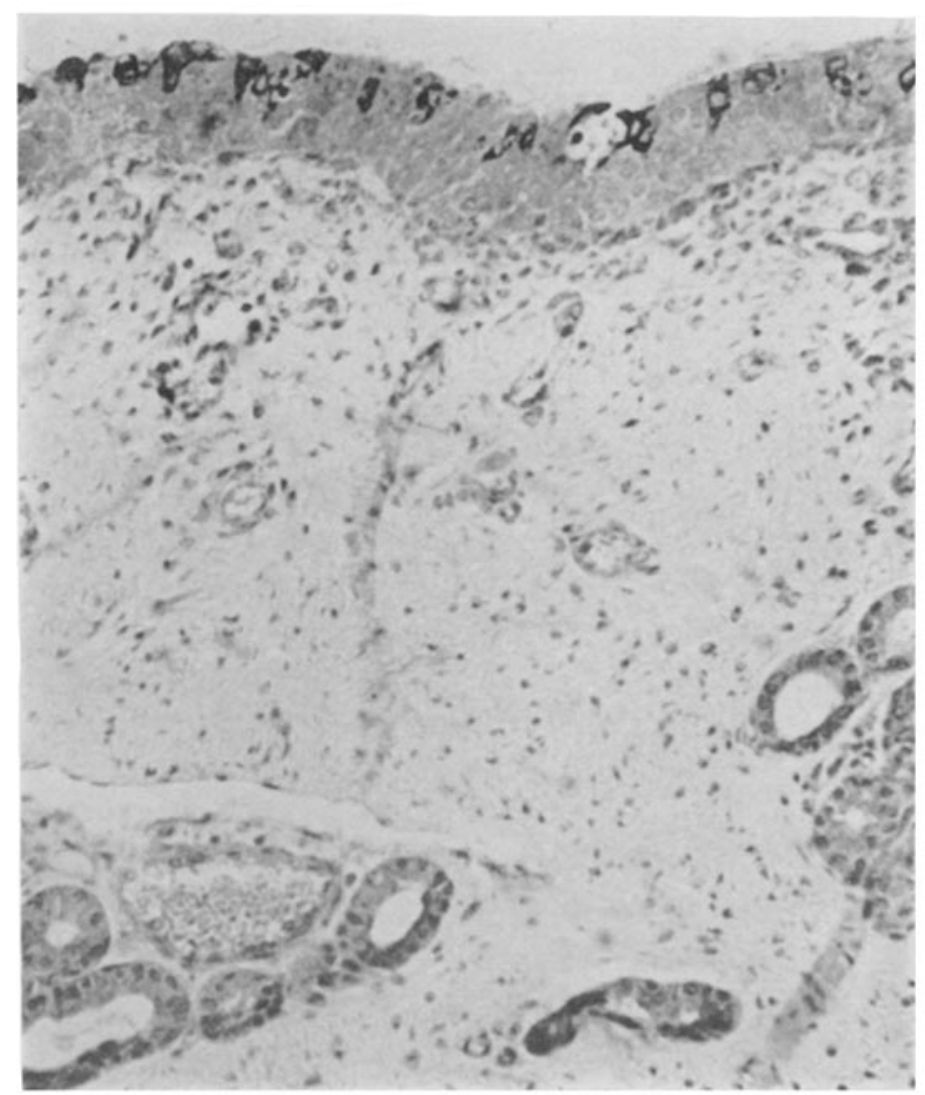

Fig. 3. Coronavirus-infected epithelial cells in the trachea of ealf 5. Indirect Immunoperoxidase stain. $\times 200$

\section{Cross-Protection in Calves}

Four calves (Table 3, calves 2, 3,6 and 7) were re-challenged 12-21 days after primary inoculation and their virus shedding was compared with three age-matched, previously uninfected animals (Table 3, calves 1,4 and 5). Calves 2 and 3 had excreted coronavirus in faeces and nasal swabs after primary inoculation with faecal material but both were immune to challenge with homologous virus 14 or 21 days later. An aliquot of the same inoculum was shown to be infective in the matched control calf (no. 1). Similarly, 
Table 3. The effect of infection with an enteric coronavirus on subsequent challenge with homologous virus or two coronaviruses derived from the respiratory tract

\begin{tabular}{|c|c|c|c|c|c|c|c|c|}
\hline \multirow[b]{3}{*}{ Calf } & \multicolumn{4}{|c|}{ First inoculation } & \multicolumn{4}{|c|}{ Challenge inoculation } \\
\hline & \multirow[b]{2}{*}{ Inoculum } & \multirow{2}{*}{$\begin{array}{l}\text { Calf age } \\
\text { (days) }\end{array}$} & \multicolumn{2}{|c|}{ 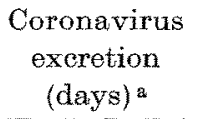 } & \multirow[b]{2}{*}{ Inoculum } & \multirow{2}{*}{$\begin{array}{l}\text { Calf age } \\
\text { (days) }\end{array}$} & \multicolumn{2}{|c|}{$\begin{array}{c}\text { Coronavirus } \\
\text { exeretion } \\
\text { (days) }^{a}\end{array}$} \\
\hline & & & NS & FS & & & NS & FS \\
\hline 1 & - & - & - & - & $\mathbf{E}$ & 24 & $5-7$ & $2-4$ \\
\hline 2 & $\mathbf{E}$ & 2 & $1-4$ & $3-6$ & $\mathbf{E}$ & $23(21)^{b}$ & 0 & 0 \\
\hline 3 & $\mathbf{E}$ & 1 & 2 & $4--5$ & $\mathrm{E}$ & $15(14)$ & 0 & 0 \\
\hline 4 & - & - & - & - & R 1 & 18 & 5 & $2-5$ \\
\hline 5 & - & - & - & - & R 2 & 13 & $1-5$ & $3-5$ \\
\hline 6 & $\mathrm{E}$ & 1 & $4-7$ & $2-5$ & R 1 & $18(17)$ & 0 & 0 \\
\hline 7 & $\mathbf{E}$ & 1 & $5-6$ & $2-5$ & $\mathrm{R} 2$ & $13(12)$ & 0 & 0 \\
\hline
\end{tabular}

a Coronavirus excretion in nasal swabs (NS) detected by immunofluorescence and in faeces (FS) by ELISA

b Interval (days) between first and challenge inoculation

$\mathrm{E}=$ Coronavirus derived from faeces

$\mathrm{R} 1$ and $\mathrm{R} 2=$ Respiratory coronavirus inoculum derived from infected nasal epithelial cells

Table 4. Infectivity titres for tissue culture of 9 coronavimuses after incubation with immane or non-immune pig serum

\begin{tabular}{|c|c|c|c|c|c|c|c|c|c|c|}
\hline \multicolumn{2}{|c|}{ Antibody } & \multicolumn{9}{|c|}{ Infectivity titre of coronavirus isolate ${ }^{a}\left(\log _{10} \mathrm{TCID}_{50} / \mathrm{ml}\right)$} \\
\hline Pig serum & Dilution & 1. & 2 & 3 & 4 & 5 & 6 & 7 & 8 & 9 \\
\hline Non-imraune & $10^{-}$ & 4.25 & 7.25 & 4.5 & 5.0 & 4.0 & 5.5 & 5.5 & 4.5 & 4.75 \\
\hline Immune 1 & $10^{-1}$ & $\langle\mathbf{1 . 5}$ & 1.75 & $<1.5$ & $<1.5$ & $<1.5$ & $<1.5$ & $<1.5$ & $\langle 1.5$ & $\langle 1.5$ \\
\hline Non-immune & $10^{-2}$ & 5.0 & 6.0 & $\mathrm{NT}$ & 6.0 & 4.0 & 6.0 & 5.5 & 4.5 & 5.25 \\
\hline Immune 2 & $10^{-2}$ & $<1.5$ & $\langle\mathbf{1 . 5}$ & $\mathrm{NT}$ & $<1.5$ & $<1.5$ & $<1.5$ & $\langle 1.5$ & $<1.5$ & $<1.5$ \\
\hline Non-immune & $10^{-2}$ & 4.5 & 6.0 & 4.75 & 5.75 & 4.5 & 5.5 & 5.75 & 4.75 & 6.0 \\
\hline Immune 3 & $10^{-2}$ & $<1.5$ & $<1.5$ & $\langle\mathbf{1 . 5}$ & $<1.5$ & $<1.5$ & $<1.5$ & $<1.5$ & $<1.5$ & $<1.5$ \\
\hline
\end{tabular}

a Isolates $1,4,5,7$ and 9 derived from intestine and 2,3,6 and 8 from respiratory tract. Homologous tests are in boldtype

$\mathrm{NT}=$ Not tested

calves 6 and 7 , infected with the enteric coronavirus, showed no evidence of colonisation when challenged with either respiratory strain 12 or 17 days later. The control animals (4 and 5) demonstrated that these viruses were capable of replication in calves of identical age which had not received the primary inoculum.

\section{Neutralisation Tests}

Coronavirus antibody titres of pig sera $1-3$ (Table 4) were 2560,1280 and 1280 by direct immunofluorescence tests. The immunising viruses were 
derived from: 1 . the strain (enteric) used as inoculum for gnotobiotic calves; 2. strain R2 from nasal epithelial cells of calf 11 in Table 2 and 3 . nasal epithelial cells of a calf with diarrhoea (Table 1) which was also excreting coronavirus in faeces. There was effective neutralisation of infectivity of each homologous coronavirus when compared with the titres in control tests with non-immune serum (Table 4). Reductions in homologous titres of at least $10^{2.7}, 10^{4.5}$ and $10^{3.25} \mathrm{TCID} \mathrm{D}_{50} / \mathrm{ml}$ were achieved. The panel of 3 sera were effective in neutralising up to 8 heterologous cloned viruses from diverse sources. A residual infectivity of $10^{1.75} \log _{10}$ TCID $_{50} / \mathrm{ml}$ was detected for isolate 2 with serum 1, although the exact titre was reduced by $10^{5.5}$ $\mathrm{TCID}_{50} / \mathrm{ml}$.

\section{Discussion}

There is strong evidence from the results of this study that bovine coronaviruses have a dual tropism for the intestinal and respiratory mucosa. However, none of the results herein indicate the existence of a substantial difference between isolates in either antigenic or pathogenic determinants.

Diagnosis in vivo of respiratory infection by coronavirus by immunofluorescence on nasal swabs was an important development. The method was first used in cattle for RSV (23) after being successfully applied to specimens from volunteers infected with $\mathrm{HCV}$ (8). A specific result can be obtained within two hours, allowing rapid identification of infected animals and it is far simpler than isolation of virus in organ culture. It was also as reliable overall as ELISA in faeces to identify infected animals.

Mean excretion periods from faeces and nasal swabs were virtually indistinguishable, although the individual data (shown in Table 3 for 9 calves only) illustrated that excretion from the different sites was not always concurrent. The study of field outbreak material also showed some discrepancy between respiratory and intestinal excretion or replication, but this was to be expected from the method of sampling which was not designed to study the course of infection.

The previous studies, which reported coronavirus growth in the respiratory tract $(9,24)$, did not test for virus shedding in faeces and did not examine specific sites for replication in the respiratory tract. Other studies on the pathogenesis of coronavirus in calves $(3,12)$ have concentrated on its effect on the gut and upper respiratory tissues have not been examined. TGEV in pigs can replicate in respiratory tissues $(6,26)$ in spite of its main predilection and pathogenicity for the gut and our results show that coronavirus behaves similarly in calves. Close examination of nasal mucosa during previous work might have revealed coronavirus antigen.

A respiratory coronavirus isolate from one calf in each series of field cases did replicate in gnotobiotic calves, was excreted by both routes and was shown to colonise both enteric and respiratory mucosal surfaces. There 
was no distinction between these and the other coronavirus isolates examined in animal or tissue culture tests for cross reactivity. More sensitive test probes for variation between viruses are now required and monoclonal antibodies might be potentially useful to differentiate between these closelyrelated isolates.

Absence of antigen from the lower respiratory tract and failure to recognise signs of respiratory disease in experimental calves indicate that coronavirus should not be considered as a candidate in the aetiology of calf pneumonia at this stage. However further studies will be required to demonstrate whether infection with coronavirus has different consequences under field conditions (9).

The current importance of its recognition in respiratory tissue lies in the implication for coronavirus epidemiology; spread of virus may occur by aerosol as well as faecal-oral transmission. In addition, it might be possible to vaccinate calves against enteric disease caused by coronavirus infection by the intranansal route of inoculation, as suggested for TGEV (18). This route could induce active intestinal immunity without primary infection in the gut and could be used in the newborn calf when local intestinal colostral antibody usually neutralises live virus vaccines given by the oral route.

\section{Acknowledgements}

We thank Mr Peter Dennis for the frozen sections, Dr. Sherine Chantler (Wellcome Research Laboratories) for conjugation of antiserum and $\mathrm{Mr}$ J. Morgan for helping to provide some of the field material. Access to field outbreaks was given by many local farmers and veterinarians.

\section{References}

1. Bridger, J. C., Woode, G. N., Meyling, A.: Isolation of a coronavirus from neonatal calf diarrhoea in Great Britain and Denmark. Vet. Microbiol. 3, 101-113 (1978).

2. Dennis, M. J., Davies, D. C., Hoare, M. N.: A simplified apparatus for the microbiological isolation of calves. Brit. Vet. J. 132, 642-646 (1976).

3. Dovghri, A. M., SToRz, J.: Light and ultrastructural pathologic changes in intestinal coronavirus infection of newborn calves. Zentralblatt für Veterinärmed. B 24, 367-385 (1977).

4. Hali, G. A., Brddger, J. C., Brooker, B. E., Parsons, K. R., Ormerod, E.: Lesions of gnotobiotic calves experimentally infected with a calicivirus like (Newbury) agent. Vet. Pathol. 21, 208-215 (1984).

5. Haralambiev, H. E., Miltov, B. K., Popov, G. V.: Isolation of bovine coronavirus and rotaviruses in organ cultures from respiratory mucosa. Compt. Rend. de l'Acad. Bulgar. Sci. 32, 1597-1600 (1979).

6. Laude, H., Charley, B., Gelfi, J.: Replication of transmissible gastroenteritis coronavirus (TGEV) in swine alveolar macrophages. J. gen. Virol. 65, 327-332 (1984). 
7. Laporte, J., Bobulesco, P., Rossr, F.: Une Lignée cellulaire particulierement sensible à la replieation due coronavirus enteritique bovin. Compt. Rend. de l'Aead. Sci. (Paris) 290D, 623 626 (1980).

8. MoIntosh, K., MoQumlan, J., ReEd, S. E., Gardner, P. S. : Diagnosis of human coronavirus infection by immunofluorescence: method and application to respiratory disease in hospitalised children. J. med. Virol. 2, 341-346 (1978).

9. MoNulty, M. S., Bryson, D. G., Altan, G. M., Logan, E. F.: Coronavirus infections of the bovine respiratory tract. Vet. Microbiol, 9, 425-439 (1984).

10. Mebus, C. A., Strair, E. L., Rhodes, M. B., Twiehaus, M. J.: Pathology of neonatal calf diarrhoea induced by a coronavirus-like agent. Vet. Pathol. 10, $45-64(1973)$.

11. Parsons, K. R., Wilson, A. M., Hall, G. A., Bridger, J. C., Chaxter, N. C, REYNoLDs, D. J.: Localisation of enteropathogens in paraffin embedded tissue by immunoperoxidase. J. Clin. Pathol. 37, 645-650 (1984).

12. Patel, J. R., Davies, H. A., Edington, N., Laporte, J., Macnaughton, M. R.: Infection of a calf with the enteric coronavirus strain Paris. Arch. Virol. 73, 319327 (1982).

13. Pocock, D. H., Garwes, D. J.: The polypeptides of haemagglutinating encephalomyelitis virus and isolated subviral particles. J. gen. Virol. 37, 487-499 (1977).

14. REED, S. E.: Coronavirus infections of the respiratory tract. Proceedings of the Fourth Munich Symposium on Microbiology, Munich, 201-216. 1979.

15. RexNolds, D. J.: Coronavirus replication in the intestinal and respiratory tract during infection of calves. Ann. Recherche Vétérin. 14, 445-446 (1983).

16. Reynotos, D. J., Thomas, L. H., Bridakr, J. C., Stott, E. J.: Coronavirus infections of cattle. Fifth International Congress of Virology, Strasbourg, 1981.

17. Reynolds, D. J., Chasey, D., Scotx, A. C., BRIDGer, J. C.: Evaluation of ELISA and electron microscopy for the deteetion of coronavirus and rotavirus in bovine faeces. Vet. Rec. 114, 397-401 (1984).

18. Sprino, P. J., Ristic, M.: Intestinal, pulmonary and serum antibody response to transmissible gastroenteritis virus by the oral-nasal routes of inoculation. Amer. J. Vet. Res. 43, 255-261 (1982).

19. Storz, R., Rotr, R., Kaluza, G.: Enhancement of plaque formation and cell fusion of an enteropathogenic coronavirus by trypsin treatment. Infect. Immun. 31, $1214-1222(1981)$.

20. Stott, E. J., Thomas, L. H., Bridger, J. C., Jebbett, N. J.: Replication of a bovine coronavirus in organ cultures of foetal trachea. Vet. Microbiol. 1, 65-69 (1976).

21. StotT, E.J., Garwes, D. J., : Respiratory coronaviruses, 7th ed. London: Topley and Wilson 1984.

22. Thomas, L. H., StotT, E. J.: Comparison of three methods for sampling the bovine upper respiratory tract for viruses. Res. Vet. Sci. 18, 227-229 (1975).

23. Thomas, L. H., Stotт, E. J.: Diagnosis of respiratory syncytial virus in the bovine respiratory tract by immunfluorescence. Vet. Rec. 108, 432-435 (1981).

24. Thomas, L. H., Gourday, R. N., Stotr, E. J., Howard, C. J., Bridger, J. C.: A search for new microorganisms in calf pneumonia by the inoculation of gnotobiotic calves. Res. Vet. Sci. 33, 170-182 (1982).

25. Toтн, T. E.: Trypsin-enhanced replication of neonatal calf diarrhoea coronavirus in bovine embryonic lung cells. Amer. J. Vet. Res. 43, 967-972 (1982). 
26. Underdahu, N. R., Mebus, C. A., Statr, E. L., Rhodes, M. D., MoGile, L. D., TwIEnaus, M. J.: Isolation of transmissible gastroenteritis virus from lungs of market weight swine. Amer. J. Vet. Res. 35, 1209-1216 (1974).

27. Wege, H., SIDDew, S., Termeulen, V.: The biology and pathogenesis of coronaviruses. Curr. Top. Microbiol. Immunol. 99, 165-200 (1982).

Authors' address: Dr. D. J. Reynouds, Ministry of Agrieulture, Fisheries and Food, Veterinary Investigation Centre, Coley Park, Reading, RG1 6DT, United Kingdom.

Received November: 1,1984 